This item was submitted to Loughborough's Research Repository by the author.

Items in Figshare are protected by copyright, with all rights reserved, unless otherwise indicated.

\title{
Anarchism and religion
}

\section{PLEASE CITE THE PUBLISHED VERSION}

https://doi.org/10.1163/9789004356894_006

\section{PUBLISHER}

Brill

\section{VERSION}

AM (Accepted Manuscript)

\section{PUBLISHER STATEMENT}

This work is made available according to the conditions of the Creative Commons Attribution-NonCommercialNoDerivatives 4.0 International (CC BY-NC-ND 4.0) licence. Full details of this licence are available at: https://creativecommons.org/licenses/by-nc-nd/4.0/

\section{LICENCE}

CC BY-NC-ND 4.0

\section{REPOSITORY RECORD}

Christoyannopoulos, Alexandre, and Lara Apps. 2019. "Anarchism and Religion". figshare. https://hdl.handle.net/2134/18221. 


\section{Anarchism and Religion ${ }^{1}$}

\section{Alexandre Christoyannopoulos and Lara Apps}

\section{Introduction}

The intersection of religious studies and anarchism has proved a fertile ground for a variety of analyses, particularly in recent years. Students and practitioners of religion have taken anarchism more seriously, and students and practitioners of anarchism have taken religion more seriously. The encounter can lead to tensions and expose unbridgeable differences, but in most cases explorations have been fruitful, opening up and investigating new avenues of thought and practice.

This dialogue is constituted by a variety of rather different conversations: sometimes anarchists are revisiting their assessment of religion; sometimes religious scholars are articulating a theology which engages with anarchism; sometimes the focus is on how specific anarchists approached religion; sometimes general parallels are drawn between anarchism and religion; sometimes religious scriptures are interpreted to point to anarchist politics; and so on. In other words, the encounter between religious studies and anarchism can concentrate on very different facets of either, and involves very different approaches, methodologies, modes and tones of enquiry. That variety reflects not only the different themes of interest to both anarchism and religious studies, but also different ontological, epistemological, and methodological approaches.

The aim of this chapter is to sketch out some of the ways in which anarchism and religious studies intersect and influence each other's imagination. The aim is not to

\footnotetext{
${ }^{1}$ This is a revised version of Alexandre Christoyannopoulos, "Anarchism and Religious Studies," in The Anarchist Imagination: Anarchism Encounters the Humanities and the Social Sciences, ed. C. Levy and S. Newman (London: Routledge, 2015).
} 
systematically present all the scholarship there is in the area, although an effort was made to encompass a high number of sources to illustrate and compile an accurate map of the different types of scholarship buzzing around this topic. As often with typologies, the divisions and categories proposed might at times be rather arbitrary, so they should not be interpreted too strictly but rather heuristically, as an attempt to overview and catalogue the territory.

The chapter is structured in four sections: the first considers some classic anarchist quarrels with religion and its institutions; the second surveys the scholarship on anarchist interpretations of founding religious scriptures and figures; the third discusses the growing interest in anarchist "theology" as distinct from scriptural exegesis; and the fourth points to the variety of historical studies on specific religious anarchist thinkers, communities and movements.

It will quickly become obvious that the dominant religion in the scholarship, and hence in this chapter, is Christianity. One reason for this might be that (at least according to the traditional narrative) anarchist thought and practice cut many of its teeth in societies in which Christianity and its institutions tended to dominate. Nonetheless, even though the main religious interlocutor in this chapter is Christianity, other traditions are still cited whenever possible and appropriate, and the arguments which apply where anarchism and Christianity meet often apply in comparable ways to other traditions too.

\section{Anarchist Critiques of Religion}

It seems sensible to begin this overview by acknowledging the frequent suspicion of, and, in some cases, outright hostility toward, religion among many anarchists. This section outlines briefly the critical views on religion expressed by several important early anarchists, as these 
have framed subsequent encounters between anarchism and religion. ${ }^{2}$ Anarchist critiques of religion target both its institutional aspects and religious belief itself, with varying emphases depending on the individual thinker.

The essence of the anarchist critique of religion is that it is a source of inequality and injustice, a lie used by the priestly class and the state to increase their power by keeping the populace in fear and ignorance. Emma Goldman put it succinctly in 1908:

Religion is a superstition that originated in man's mental inability to solve natural phenomena. The Church is an organized institution that has always been a stumbling block to progress. Organized churchism has stripped religion of its naiveté and primitiveness. It has turned religion into a nightmare that oppresses the human soul and holds the mind in bondage. ${ }^{3}$

This critique was articulated earlier, by the anti-clerical, materialist and atheist writers of the late seventeenth and eighteenth centuries, some of whom, such as the atheist priest Jean Meslier, also expressed anarchistic hostility to property, law and government. William Godwin, who is regarded generally as the progenitor of modern anarchism, cited the Baron d'Holbach's atheist treatise The System of Nature (1770) as a key influence on his own thinking.

In Enquiry Concerning Political Justice (1793), Godwin did not dwell on the issue of the existence of God or the truth of religion. His main concern regarding religion was its lack of utility to the cause of moral improvement. Godwin argued that literature, education and political justice lead to moral improvement; there is no role for religion, which merely enslaves humanity

\footnotetext{
${ }^{2}$ For other overviews of classic anarchist criticisms and their main proponents, see, for instance, H. Barclay, "Anarchist Confrontations with Religion," in New Perspectives on Anarchism, ed. N. Jun and S. Wahl (Lanham, MD: Lexington, 2010), 169-188; J. Ellul, Anarchy and Christianity, trans. G. W. Bromiley (Grand Rapids, MI: William B. Eerdmans, 1991); and N. Walter, “Anarchism and Religion,” The Raven 25:7 (1994), 3-9.

3 A.K. Shulman, Red Emma Speaks: An Emma Goldman Reader, 3rd edition (Amherst, NY: Humanity Books, 1996), 7.
} 
through shame and superstition, and is only able to do so because it is supported by government. ${ }^{4}$ Further, religious establishments and the demand for religious conformity require "blind submission” and thus turn people into hypocrites who must outwardly profess adherence to the articles of their faith even when they disagree with them or do not believe them. ${ }^{5}$ The clergy, who are supposed to provide moral instruction to the laity, are intellectually inflexible, hypocritical men "whose business it should seem to be to dupe their contemporaries into the practice of virtue." ${ }^{6}$ Godwin also argued that the government should not compel anyone to support a religious institution: "If public worship be conformable to reason, reason without doubt will prove adequate to its vindication and support. If it be from God, it is profanation to imagine that it stands in need of the alliance of the state. It must be in an eminent degree artificial and exotic, if it be incapable of preserving itself in existence, otherwise than by the inauspicious interference of political institution."7 Finally, he argued against the suppression of religious and political "heresy," on the grounds that ignorance does not lead to virtue and that the exploration of different opinions is not subversive; it is only when a government attempts to suppress opinions that citizens will disturb the peace by fighting back. The outcome is especially violent when governments support particular religions: “The moment government descends to wear the badge of a sect, religious war is commenced, the world is disgraced with inexpiable broils and deluged with blood.”8

Like Godwin, Peter Kropotkin argued that morality did not depend on religion. In Anarchist Morality (1898), he theorized that "the moral sense is a natural faculty in us like the

\footnotetext{
${ }^{4}$ William Godwin, Enquiry Concerning Political Justice, 2 vols. (Dublin: Luke White, 1793), I:28-29.

${ }^{5}$ Ibid., II:151-152.

${ }^{6}$ Ibid., II:154.

${ }^{7}$ Ibid., II:155

8 Ibid., II:160.
} 
sense of smell or of touch.” ${ }^{9}$ All animal and human societies possess the principle of treating others as we would like to be treated under similar circumstance; this natural, innate principle has been "filched" by law and religion "to cloak their own wares, their injunctions for the benefit of the conqueror, the exploiter, the priest. ${ }^{10}$ Not only is religion unnecessary for morality, but the state and the church, working together to dominate and oppress mankind through violence and fear, have poisoned and perverted our moral sense, which has led to a society in which human nature is degraded by exploitation and servitude. In order to recover its true morality, we must reject law, religion and authority, all of which conspire to perpetuate submissiveness.

Both Mikhail Bakunin and Pierre-Joseph Proudhon developed extended critiques of religion that included accounts of its origin and development. In God and the State, Bakunin suggests that although belief in divinity was a necessary stage in humanity's evolution from a purely animal state, it is a form of slavery and collective insanity that must be eradicated. For Bakunin, the idea of God as a perfect being creates a necessarily negative view of humanity as God's opposite and inferior: “God being truth, justice, goodness, beauty, power, and life, man is falsehood, iniquity, evil, ugliness, impotence, and death. God being master, man is the slave."11 All religions "debase and corrupt" humanity by destroying reason, encouraging ignorance, dishonouring human labour, killing human pride and dignity, and making humans cruel toward each other. ${ }^{12}$ Religions persist because the majority of people are still ignorant, weighed down by economic oppression, and deprived of the education and leisure to emancipate themselves from the idea of God. People turn to "the dram-shop and the church, debauchery of the body or

\footnotetext{
${ }^{9}$ Peter Kropotkin, Kropotkin’s Revolutionary Pamphlets, ed. R. Baldwin (New York: Dover, 1970), 98.

${ }^{10}$ Ibid.

${ }^{11}$ Mikhail Bakunin, God and the State (New York: Dover, 1970), 24.

12 Ibid., 25.
} 
debauchery of the mind" in order to escape the misery of their wretched material and intellectual conditions. Only a social revolution "will have the power to close at the same time all the dramshops and all the churches" by allowing the full development of humanity in freedom. ${ }^{13}$ Bakunin took the non-existence of God for granted, but Proudhon interrogated the meaning of the idea of God, suggesting in What Is Property? that the original, primitive idea of Divinity has never been successfully defined and that anthropomorphism distorts or disfigures the idea of God. Further distortion results from the treatment of God as a possession: "Represented in such monstrous form, God became everywhere the property of man and the state." ${ }^{\prime 14}$ This is the origin of the corruption of morals by religion and is the source of pious hatreds and holy wars. Freedom of religion and separation of religious and secular authority will reduce these destructive influences of religion; religion is not, however, the primary cause of inequality and suffering, which stem from humans being at war with themselves. ${ }^{15}$

Proudhon extended his examination of the idea of God in System of Economical Contradictions. He introduces the work with a lengthy consideration of what he calls the hypothesis of God, explaining that "God is nothing more than collective instinct or universal reason”- a way for humans to understand their own self-consciousness within the world. ${ }^{16}$ Although he argues that the existence of God cannot be affirmed without empirical demonstration, which is lacking, he concludes that the "hypothesis" still stands because it cannot be disproven. In part of his analysis, Proudhon elaborates on the classic problem of why evil exists in a world created and ruled by a benevolent God, arguing that if God exists, he has not

\footnotetext{
13 Ibid., 16-17.

${ }^{14}$ Pierre-Joseph Proudhon, What Is Property?, ed. and trans. D.R. Kelley and B.G. Smith (Cambridge: Cambridge University Press, 1994), 21.

15 Ibid., 20-21.

${ }^{16}$ Pierre-Joseph Proudhon, System of Economical Contradictions, vol. 1, trans. B. Tucker [1888] (New York: Arno Press, 1972), 5.
} 
only allowed evil to exist in the world, but has created the conditions for human suffering by leaving us at the mercy of our own intellectual and moral limitations: "God, whom faith represents as a tender father and a prudent master, abandons us to the fatality of our incomplete conceptions; he digs the ditch under our feet; he causes us to move blindly: and then, at every fall, he punishes us as rascals." ${ }^{17}$ In other words, if God is in fact benevolent, he would not abandon us to our own worst natures. Since he has, if he exists, so abandoned us, he is evil and “a being deserving of hell." ${ }^{18}$ As a consequence,

the first duty of man, on becoming intelligent and free, is to continually hunt the idea of God out of his mind and conscience. For God, if he exists, is essentially hostile to our nature, and we do not depend at all on his authority. We arrive at knowledge in spite of him, at comfort in spite of him, at society in spite of him; every step we take in advance is a victory in which we crush Divinity. ${ }^{19}$

Intellectual honesty requires an acknowledgement that we cannot know whether God is real or not, but since he is our enemy, then "practical atheism" is the only reasonable course to follow. ${ }^{20}$ Bakunin's and Proudhon's negative views of God are echoed in Sébastien Faure’s Does God Exist? Twelve Proofs of the Nonexistence of God (1908), in which Faure argued that if God exists, then he is responsible for both physical and moral evil, and humans are slaves. ${ }^{21}$ Faure was not, however, taking the idea of God's existence seriously, as Proudhon does, but using this argument to attack the religious conception of God as benevolent and perfect. Like the other anarchist thinkers considered so far, Faure regarded religion as having oppressed humanity by

${ }^{17}$ Ibid., 445.

18 Ibid., 446.

19 Ibid., 448.

${ }^{20}$ Ibid., 468.

${ }^{21}$ Sébastien Faure, Does God Exist? Twelve Proofs of the Nonexistence of God [Douze preuves de l'inexistence de Dieu, 1908], available online at http://theanarchistlibrary.org/library/sebastien-faure-does-god-exist. 
encouraging superstition and demanding submissiveness. In The God Pestilence (1887), Johann Most attacked the Jewish and Christian God as a cruel despot, a specter fabricated by scoundrels, and a pestilence of the mind. ${ }^{22}$ Max Stirner also invoked the imagery of specters, arguing in Art and Religion (1842) that God, the spirit, and so on are fixed ideas, or "wheels in the head" that haunt us; those who cling to such fixed ideas, particularly to the idea of the divine, are fools. ${ }^{23}$ This critique of religion, however, is part of Stirner's general critique of fixed ideas, which include conventional morality, legality, truthfulness, and love.

Errico Malatesta offered a somewhat different perspective on religion. While certainly agreeing with other anarchist thinkers that "religion ought to wither away along with every cult through which men's ignorance and priests' cunning have manifested themselves," Malatesta argued that "the religious question ... is an economic question," and that failure to grasp this fact is what has prevented "the apostles of Freethought" from converting the masses. ${ }^{24}$ Dismissing the issue of religious truth as effectively irrelevant, Malatesta focuses on the organization of the church, pointing out that it matches the organization of the state in every way except that the church uses fraud rather than force to persuade the people to turn their possessions over to it. ${ }^{25}$ He also points out that if the priestly class's contribution to society is prayer, it makes a living out of praying and thus evades its obligation to do actual labor. As Malatesta puts it, the priest is "nothing but a collector of ecclesiastical taxes." 26

22 Johann Most, The God Pestilence [Die Gottespest, 1887], available online at http://dwardmac.pitzer.edu/ Anarchist_Archives/bright/most/godpest.html.

${ }^{23}$ Max Stirner, Art and Religion [Kunst und Religion, 1842], trans. L. Stepelevich, available online at http://theanarchistlibrary.org/library/max-stirner-art-and-religion.

${ }^{24}$ Errico Malatesta, The Method of Freedom: An Errico Malatesta Reader, ed. D. Turcato (Oakland, CA: AK Press, 2014), 42.

25 Ibid., 25-26.

${ }^{26}$ Ibid., 27. 
While these anarchist thinkers share a negative view of religion that can, as we suggested above, be boiled down to certain core elements, this brief survey shows that not all anarchist critiques of religion are the same. It is important to consider that each critique is embedded within a matrix of related ideas about authority, equality, the nature of the world, human psychology, and so on. Another important aspect of these critiques is that although these thinkers targeted Christianity, they intended their criticisms to apply to all religions. Finally, as Colin Ward has noted, anarchists and other nineteenth-century political thinkers believed that religion was on the wane and would fade away, especially if encouraged to do so through education of the masses and amelioration of their living conditions. ${ }^{27}$ This has not happened: the twentieth and twenty-first centuries have seen a resurgence of religious commitment that presents a serious challenge to the idea that religion will inevitably fade away. Anarchists must still, then, reckon with religion and its impact on the societies they wish to change.

The anarchist critique of religion is certainly open to challenge and qualification. There is not enough space here to address the complex history of the relationship between religion(s) and the state, which includes persecution of religious groups by the state and by other religious groups, as well as power struggles between secular and religious authorities. To give just one example, during the Protestant Reformation of the sixteenth century, radical religious groups such as the Anabaptists were both anticlerical and opposed to secular authority; ${ }^{28}$ modern history, too, provides examples of religiously-motivated protest and resistance. From an atheist perspective, however, which holds that religion is at best a misperception and at worst a deception peddled by elites to keep the masses in stupefied submission, empirical counter-

\footnotetext{
${ }^{27}$ C. Ward, Anarchism: A Very Short Introduction (Oxford: Oxford University Press, 2004).

${ }^{28}$ See H.-J. Goetz, "Radical Religiosity in the German Reformation," in A Companion to the Reformation World, ed. R. Po-Chia Hsia (Malden, MA: Blackwell Publishing, 2004), 70-85.
} 
examples to the narrative of church collusion with the state do not attenuate the forcefulness of their criticisms of religion.

The view of God as a despotic master may also be challenged; significant currents within religious traditions have been critical of their own patriarchal structures, and "gods" are not always or only defined as “masters.” As Alexis-Baker notes, in the Christian Bible, “God is also identified as Creator, Liberator, Teacher, Healer, Guide, Provider, Protector and Love,” so that anarchists and Christians alike who are "making monarchical language the primary descriptor of God” in fact “misrepresent” his "full character." 29 To understand God as a despot is therefore to misunderstand the varieties of the multifaceted understandings of "God" even within the Christian tradition. Again, however, since from an atheist perspective a multifaceted God is still a delusion, such views may have little impact.

For some anarchists, the same consistent critical thinking which leads to anarchism must also lead to atheism. ${ }^{30}$ Some go as far as to almost see an avowed anarchist's atheism as one of the measures of their commitment to an anarchist approach. Certainly atheists have been strongly represented in the writings of many classical anarchists and in many anarcho-syndicalist circles. Atheism is not, however, a strictly necessary precondition for reaching anarchist conclusions: as the following sections of this chapter show, the two sets of conclusions do not depend on each other, and even though they can reinforce each other, a dismissal of all religion following atheist arguments is analytically separable from the dismissal of the religious, political and economic establishment following anarchist arguments.

\footnotetext{
29 N. Alexis-Baker, “Embracing God, Rejecting Masters,” Christianarchy 1:2 (2005), 2.

30 See, for example, T. Gibson, “Should We Mock at Religion?,” The Raven 25:7 (1994), 8-10.
} 
Despite the substantial (though varied) hostility to religion in anarchist milieus, many anarchists today nonetheless display considerable tolerance of their religious comrades, an openness to respectful yet critical discussions of unfamiliar perspectives, and a willingness to leave some of their differences on religion aside in their shared contemporary struggles against various forms of oppression. Indeed, as Barclay shows, even several classical anarchists had some sympathy for some aspects of the religions they encountered-such as the emphasis on love and mutualism in the teachings of Jesus, the radical politics of some religious sects and movements, and so on. ${ }^{31}$ Kropotkin's famous entry on anarchism in the Encyclopaedia Britannica provides one example of this, ${ }^{32}$ and Gérard Bessière’s Jésus selon Proudhon discusses Proudhon's productive fascination with the figure of Jesus and his conclusion that Jesus was a social and moral reformer whose message was corrupted and "spiritualized" by Paul and his generation. ${ }^{33}$ John Clark's "Anarchism” entry in the Encyclopedia of Religion and Nature also paints a detailed picture of "anarchist tendencies across history that have held a spiritual view of reality," thus showing that the meeting of anarchist and religious currents is not new. ${ }^{34}$ Hostility to all aspects of religion, therefore, is not a trait universally shared by all anarchists.

Furthermore, as some scholars have argued, certain possibly unnoticed or unacknowledged parallels can be identified between anarchism and religion. Aurelio Orensanz's Anarquia y Cristianismo discusses the strong similarities between several central Christian

\footnotetext{
31 Barclay, “Anarchist Confrontations with Religion,” 170, 172.

32 Peter Kropotkin, “Anarchism,” in Encylopaedia Britannica, 11 $1^{\text {th }}$ edition (New York: The Encyclopaedia Britannica Co., 1910), 914-919: 919.

33 G. Bessière, Jésus selon Proudhon: la «messianose » et la naissance du christianisme (Paris: Cerf, 2007).

34 J. Clark, “Anarchism,” in Encyclopedia of Religion and Nature, ed. B. Taylor (London: Continuum, 2005), 49-56: 49.
} 
themes and values and those propounded by anarchists (in particular Bakunin, interestingly); ${ }^{35}$ Keith Hebden's “Building a Dalit World in the Shell of the Old” examines the parallels between anarchism (as defined by Colin Ward) and Dalit values and practice; ${ }^{36}$ and Demetrio Castro Alfín’s “Anarquismo y Protestantismo” considers the parallels between the anticlericalism of nineteenth- and twentieth-century Andalusian anarchist peasants and that of sixteenth- and seventeenth-century protestant agitators. ${ }^{37}$ In other words, certain views and practices can be found in both anarchist and religious groups.

Finally, it is worth atheist anarchists bearing in mind that too cavalier a dismissal of religion can have regrettable effects in alienating potential allies and comrades emerging from different journeys yet keen to share and build bridges. Erica Lagalisse's "Marginalizing Magdalena” examines some of the pitfalls of the typical antireligious prejudice among anarchists by reflecting (from a feminist, anti-colonial perspective) on the marginalization of a female Oaxacan activist during a speaking tour in Canada. ${ }^{38}$ What can be dismissed as "religion" includes many aspects and phenomena (beliefs, communal practices, moral commitments, etc.), and whilst anarchists might converge in denouncing domination and oppression, it may be that today many of those facets of "religion" are not the main sources of domination-indeed, as many secular anarchists have recognized, there is much to learn from religious comrades in the struggle against structures of oppression (including their own). Besides, if Paul-François Tremlett (2004) is correct that in early anarchist writings, “religion” as a category was formed

\footnotetext{
35 A. Orensanz, Anarquia y Cristianismo (Madrid: Mañana, 1978).

${ }^{36}$ K. Hebden, "Building a Dalit World in the Shell of the Old: conversations between Dalit indigenous practice and Western anarchist thought," in Religious Anarchism: New Perspectives, ed. A. Christoyannopoulos (Newcastle upon Tyne: Cambridge Scholars Publishing, 2009), 145-165.

${ }^{37}$ D. Castro Alfin, "Anarquismo y Protestantismo: reflexiones sobre un viejo argumento," Studia Historica: Historia Contemporánea 16 (1998), 197-220.

${ }^{38}$ E.M. Lagalisse, “'Marginalizing Magdalena': Intersections of Gender and the Secular in Anarchoindigenist Solidarity Activism,” Signs 36 (2011), 653-78.
} 
and functioned as "a cipher for thinking about the past" (whether as something that was looked back at nostalgically or as something that needed to be overcome), then perhaps the broader context has evolved enough for the time to have come to reconsider the variety of facets and experiences of "religion" and work with those religious people who share many of the goals of fellow anarchists. ${ }^{39}$

\section{Anarchist Exegesis}

Having outlined and discussed some of the traditional suspicions of religion among anarchists, it is time to look at examples of more favorable interactions. One example of a positive encounter comes from studies that interpret religious scriptures to advocate anarchism or to otherwise imply anarchist conclusions - that is to say, anarchist exegesis. Here, the "anarchism" is in the political deductions of those scriptural interpretations, in other words in the criticisms of the state, capitalism and other structures of oppression-including indeed many aspects of "religion"- that these interpreters derive from major religious texts. This approach therefore refuses to dismiss all religion a priori, reads foundational religious texts, and finds their line of reasoning to lead to anarchist conclusions. Alexandre Christoyannopoulos’s Christian Anarchism considers many examples of notorious anarchist exegeses and weaves them together to present a relatively generic and systematic anarchist interpretation of the Christian gospels. ${ }^{40}$ Here is not the place to discuss in depth the precise contribution of every Christian anarchist exegete, but a brief outline of the main interpretations might help illustrate some of the variety of styles and focuses involved.

\footnotetext{
${ }^{39}$ P.-F. Tremlett, “On the Formation and Function of the Category 'Religion”' in Anarchist Writing," Culture and Religion 5 (2004), 367-81: 367.

40 A. Christoyannopoulos, Christian Anarchism: A Political Commentary on the Gospel (Exeter, UK: Imprint Academic, 2010).
} 
The author who is traditionally cited in anarchist circles as the primary example of Christian anarchism is Leo Tolstoy, and the most frequently cited book is his Kingdom of God Is within You. ${ }^{41}$ In it, Tolstoy covers at length topics such as military service, state violence and revolutionary methods, and defends his interpretation of Christianity against what he sees as perversions of it. That book, however, was originally written in response to the reception of his earlier and more methodical exegesis published as either What I Believe or My Religion, which outlines Tolstoy's analysis of Jesus' teaching in more meticulous detail. ${ }^{42}$ Very interesting too is Tolstoy's harmonized and translated version of the gospels ("The Gospel According to Leo," as it were), which by what it includes and excludes illustrates how Tolstoy interprets the four canonical scriptures. ${ }^{43}$ As an exegete, however, Tolstoy was quite a maverick. He rejected and ignored everything he saw as irrational, and focused squarely on the moral teaching of Jesus. He also ignored much of the Old Testament, Paul's epistles and the rest of the New Testament. Predictably, therefore, his exegetical approach has been widely criticized, and it may not be surprising that even in Christian radical circles Tolstoy tends to be approached with caution. Nonetheless, one of the merits of his exegesis is its stubborn refusal to shy away from the logical implications of Jesus' teaching with regards to the state's perpetration and legitimation of violence- - a topic on which he writes as well as can be expected from the author of acclaimed works of fiction.

Less unconventional as an exegete and more respected as a theologian is Jacques Ellul. A prolific scholar, he wrote dozens of volumes, several of which interpret specific books and

\footnotetext{
${ }^{41}$ L. Tolstoy, “The Kingdom of God Is Within You” [1893], in The Kingdom of God and Peace Essays, trans. A. Maude, New Delhi: Rupa, 2001).

${ }^{42}$ L. Tolstoy, What I Believe [1884], trans. F. Mayo (London: C.W. Daniel, 1902).

${ }^{43}$ L. Tolstoy, The Four Gospels Harmonised and Translated [1881] (London: Walter Scott, 1895); L. Tolstoy, "The Gospel in Brief" [1881], in A Confession and the Gospel in Brief, trans. A. Maude (London: Oxford University Press, 1933), 146-238.
} 
passages of the Bible. He gained particular notoriety for his critique of what he called our société technicienne (usually translated as "technological society"), a society in which the obsession with efficiency overrides ethical concerns. His most explicitly anarchist contribution to biblical exegesis, however, came in the chapter "Anarchism and Christianity" 44 and the short book Anarchy and Christianity. ${ }^{45}$ In these works, Ellul offers an explicitly anarchist interpretation of several Bible passages, including some largely ignored by Tolstoy, such as the Old Testament Book of Samuel, "render unto Caesar" (which Tolstoy deals with rather hastily) and the Book of Revelation. Although he does not match the piercing eloquence of Tolstoy's denunciation of state violence, both Ellul's coverage of the Bible and his theological approach are more conventional than Tolstoy's, making him more amenable for contemporary Christians to identify and engage with.

Several other writers have published explicitly anarchistic exegeses of Christian scripture. One somewhat controversial example is Vernard Eller's Christian Anarchy, which proposes a reading of Romans 13 which has not always been well received by Christian anarchists and poses problems for secular anarchists, yet nonetheless articulates clear criticisms of the state despite the counter-intuitive method it proposes to subvert it. ${ }^{46}$ Other anarchist exegeses include Niels Kjær’s Kristendom og Anarkisme, Michael Elliott’s Freedom, Justice, and Christian Counter-Culture, Dave Andrews’ Christi-Anarchy, Matt Russell’s “Anarchism and Christianity,” and Mark Van Steenwyk’s That Holy Anarchist, each of which reflects on Jesus' teaching, often contrasts it with the mainstream church interpretation of it, and gives

\footnotetext{
44 J. Ellul, “Anarchism and Christianity,” Jesus and Marx: From Gospel to Ideology, trans. J. Main Hanks (Grand Rapids, MI: William B. Eerdmans, 1998), 153-177; J. Ellul, Anarchy and Christianity, trans. G. W. Bromiley (Grand Rapids: William B. Eerdmans.

${ }^{45}$ See note 2 above.

${ }^{46}$ V. Eller, Christian Anarchy: Jesus’ Primacy Over the Powers (Eugene, OR: Wipf and Stock, 1987).
} 
examples of Christian communities that have tried harder than the mainstream to remain faithful to it. ${ }^{47}$

Further examples include David Alan Black’s Christian Archy, which revisits the meaning of God’s “kingdom” in the New Testament; ${ }^{48}$ Tom O’Golo’s Christ? No! Jesus? Yes!, which argues that Jesus and his first followers were anarchists and that Paul corrupted Christianity; ${ }^{49}$ Greg Boyd’s “The Bible, Government and Christian Anarchy,” which comments on a variety of biblical texts in support of an anarchist interpretation; ${ }^{50}$ Nekeisha Alexis-Baker's “The Church as Resistance to Racism and Nation,” which looks to scripture to describe how the church can embody an opposition to both the idea of race and the nation-state; ${ }^{51}$ and Peter Pick’s “A Theology of Revolutions,” which analyses Abiezer Coppe’s use of the Bible as a weapon against the earthly authorities of his day. ${ }^{52}$ There are therefore numerous examples of explicitly anarchist exegeses, many written relatively recently.

Also noteworthy, because cited by contemporary Christian anarchists, are exegeses which, even though not explicitly anarchistic, come very close to it because of their criticism of violence or of political elites, such as John Howard Yoder's Politics of Jesus, Ched Myers' Binding the Strong Man, and Walter Wink's studies of the "powers." 53 (1984; 1986; 1992). A

${ }^{47}$ N. Kjær, Kristendom og Anarkisme (Aarhus, 1972), available online at http://archive.org/details/KristendomOg Anarkisme; M.C. Elliott, Freedom, Justice and Christian Counter-Culture (London: SCM, 1990); D. Andrews, Christi-Anarchy: Discovering a Radical Spirituality of Compassion (Oxford: Lion, 1999); M. Russell, "Anarchism and Christianity" (2004), available online at http://news.infoshop.org/article.php?story=04/09/14/5885651; M. Van Steenwyk, That Holy Anarchist: Reflections on Christianity and Anarchism, Minneapolis: Missio Dei, 2012).

${ }^{48}$ D.A. Black, Christian Archy (Gonzalez, FL: Energion, 2009).

49 T. O’Golo, Christ? No! Jesus? Yes!: A Radical Reappraisal of a Very Important Life (St Andrews: Zimbo, 2011).

${ }^{50}$ G. Boyd, The Bible, Government and Christian Anarchy (2008), available online at http://reknew.org/2008/01/ the-bible-government-and-christian-anarchy/.

${ }^{51}$ N. Alexis-Baker, "The Church as Resistance to Racism and Nation: A Christian, Anarchist Perspective," in Christoyannopoulos, Religious Anarchism, 166-201.

52 P. Pick, “A Theology of Revolutions: Abiezer Coppe and the Uses of Tradition,” in ibid., 30-46.

53 J.H. Yoder, The Politics of Jesus (Grand Rapids, MI: William B. Eerdmans, 1994); C. Myers, Binding the Strong Man: A Political Reading of Mark's Story of Jesus (Maryknoll, NY: Orbis, 1988); W. Wink, Naming the Powers: 
further example worth a short discussion is Shane Clairborne and Chris Haw's Jesus for President (2008) with its associated website, YouTube clips, speaking tours and DVDs. ${ }^{54}$ Written primarily for US Christians and adopting a format which is quite lively and colourful (it is full of drawings, pictures, and other graphics), their book aspires to "provoke the Christian political imagination” beyond the narrow confines of electoral politics. However, perhaps to minimize the risk of alienating its readership and maximize the chances of convincing it, the word "anarchism" seems deliberately and systematically avoided. Yet its exegesis, its commentary on church history, and its reflections on the political engagement of contemporary Christians are all strikingly anarchistic, similar to and indeed often relying on the writings of several of the authors cited above.

In a sense, these exegeses tend to focus their direct criticism on the state, and to some extent the church, more than on capitalism, even though many secular anarchists today see capitalism as at least as dangerous as the state. Of course, the precise nature of the overlap, interaction and mutual reinforcement of "the state" and "capitalism" is complex and evolving, and whether there even is a single and primary source of "evil" in the global political economy is debatable. Besides, Christian anarchists do frequently interpret scriptural passages as challenging contemporary economic orthodoxies, and they do frequently criticize the capitalist system on that basis. However, their arguments from scripture to the state seem to require fewer logical steps than those from scripture to capitalism. It is presumably easier to interpret ancient scripture to denounce the political and religious establishments (although of course, the state today is a

The Language of Power in the New Testament (Philadelphia: Fortress, 1984); W. Wink, Unmasking the Powers:The Invisible Forces That Determine Human Existence (Philadelphia: Fortress, 1986); W. Wink, Engaging the Powers: Discernment and Resistance in a World of Domination (Minneapolis: Fortress, 1992).

${ }^{54}$ S. Clairborne, S. and C. Haw, Jesus for President: Politics for Ordinary Radicals (Grand Rapids, MI: Zondervan, 2008). 
rather complex phenomenon too) than it is to denounce the complex web of interests and the instruments of oppression that form the "establishment” in the globalized capitalist economy. Still, whether borrowing Hardt and Negri’s notion of “empire” in pamphlets such as Jason Barr’s Radical Hope (2008) or in numerous Iconocast podcasts (Iconocast Collective 2013), denouncing responses to the financial crisis in Christian anarchist blogs and newspapers, or turning some classic submissive passages from the King James translation of the Bible into an empowering call to "occupy the land" and "cast wickedness into the furnace of fire” (Nemu 2012), contemporary Christian anarchists do spend much time denouncing the current economic order. $^{55}$ To date, however, Christian criticisms of capitalism rooted directly in exegesis tend to be less ubiquitous and less developed than those of the state or church.

In any case, anarchist interpretations of religious scripture are not restricted to Christianity. In Islam, for instance, both Mohamed Jean Veneuse’s Anarca-Islam and Abdennur Prado’s El Islam como Anarquismo Místico demonstrate that the Koran can be interpreted anarchically as an anti-authoritarian, anti-capitalist and anti-patriarchal text - indeed, also (just as the Christian gospel) as a text critical of the religious establishment. ${ }^{56}$ These studies, however, seem to be the first detailed attempts at such exegesis so far (at least in English). Outside monotheistic traditions, John Clark's Master Lao and the Anarchist Prince aims to show that "the Daodejing is in accord with [...] holistic ecological anarchism," 57 and in Zen Anarchy Max

\footnotetext{
55 J. Barr, Radical Hope: Anarchy, Christianity, and the Prophetic Imagination (2008), available online at http://propheticheretic.files.wordpress.com/2008/03/radical-hope-anarchy-christianity-and-the-propheticimagination.pdf; Iconocast Collective, The Iconocast (2013), available online at http://www.jesusradicals.com/ category/iconocast/; D. Nemu, Mistranslation and Interpretation in the Service of Empire (2012), available online at http://vimeo.com/50409919.

56 M.J. Veneuse, Anarca-Islam (2009), available online at http://theanarchistlibrary.org/library/mohamed-jeanveneuse-anarca-islam; A. Prado, El Islam como Anarquismo Místico (Barcelona: Virus, 2010).

${ }^{57}$ J. Clark, Master Lao and the Anarchist Prince (n.d.), available online at http://anarvist.freeshell.org/JohnClark/ MASTER_LAO_AND_THE_ANARCHIST_PRINCE_by John_Clark.html.
} 
Cafard (Clark’s alter-ego) similarly argues that Zen was always meant to be anarchic, indeed that it is "the practice of anarchy," and demonstrates this through an interpretation of respected Zen and Buddhist writings and teachings. ${ }^{58}$

In short, there are numerous examples of interpretations of scripture that lead to anarchist conclusions. These examples do of course illustrate the paradox of anarchism derived from scriptural authority. Even if the conclusion is an anarchist critique of the state, the economy or even of religion, secular anarchists may still justifiably denounce the "revealed" point of departure as not very anarchist. Yet that is also the strength of that position. Within contemporary religious circles, appeal to scriptural authority can act as a theological trump card, and religious anarchists have sometimes used it in precisely this way. When a holy text can be convincingly and consistently argued to imply an anarchist position, this can help persuade coreligionists. Anarchist exegesis therefore provides an essential line of reasoning for religious anarchist arguments.

\section{Anarchist Theology}

"Theology" is a term that can be misunderstood in non-religious circles, and sometimes the word "theological” gets used almost as a synonym for "religious." Yet theology refers to a specific mode of inquiry and understanding, one that is more deeply rooted in religion than "religious studies.” It follows a style of argument which is more contemplative, which often assumes "belief," and which thinks within (and uses the language of) religious traditions. Compared to exegesis, therefore, theology is less concerned with scripture and its interpretation, and more with approaching specific questions and themes (such as war, evil, peace, justice, love) from a

\footnotetext{
${ }^{58}$ M. Cafard, Zen Anarchy (2013), available online at http://raforum.info/spip.php?article3503.
} 
particular religious or cosmological understanding. Theology ultimately seeks to remain faithful to scripture, but not reduced to it.

There is some debate within religious studies as to whether the term "theology" should be applied only to Christian or at least monotheistic thought, or whether it can be used to describe the similar thinking and philosophy which can emerge from any religious tradition. Yet even though some religions have no deity ("theos") to "reason" ("logos") about, Christianity is not the only religion to engage in the mode of reflection rooted within a religious tradition which is described by the term: "theology." Hence, although somewhat ethnocentric, the word does name a type of investigation which is not necessarily restricted to Christian thought. Therefore, the label of "anarchist theology" can similarly be applied to anarchist reflections rooted in any religious tradition, thus helping differentiate such mode of thinking from a more exegetical one focused on interpreting foundational texts.

At the same time, the boundary between exegesis and theology is not a rigid one. Theological discussions are not necessarily directly and hurriedly rooted in scripture, but many ultimately are. Exegetical discussions can be quite narrowly focused on the specific verses they seek to interpret, but frequently evoke theological ideas and debates which have matured within their religious tradition. In short, "exegesis” and "theology” point to two types of analyses which are driven by different primary concerns, but are nonetheless complementary and often used together. For instance, Christian anarchists have contributed to theological discussions on restorative justice (theology), and they have articulated a detailed interpretation of the Sermon on the Mount (exegesis), but they have also criticized mainstream theological developments such as just war theory on the basis of scripture (both). 
However, not all Christian anarchism is merely about scripture, and several Christian anarchists have been articulating theological considerations of specific contemporary questions. Clairborne and Haw's Jesus for President and Ted Lewis' Electing Not to Vote both address the themes of elections and voting; ${ }^{59}$ Ellul's Violence ponders the topic of violence from a variety of Christian perspectives; ${ }^{60}$ Keith Hebden's Seeking Justice blends personal experience and theology, and more broadly stories and theory, to explore ways in which activists can be inspired to challenge unjust structures today; ${ }^{61}$ and Ronald Osborn's collection of essays reflects from a radical perspective influenced by Tolstoy and Chomsky on a number of topics related to war and political power including Obama's Nobel Prize, the political contribution of the Seventh-day Adventist Church, and the Vietnam War. ${ }^{62}$ These publications all seek to address specific themes and debates grounded within an anarchist-leaning Christian tradition.

Such theological discussions often engage with and find support in existing theological schools of thought which, although not reaching explicitly anarchist conclusions, have developed arguments which are sympathetic to it. For instance, much "theology of liberation" considers themes close to anarchism. Its critique of oppression and of the capitalist economy and its preference for grassroots and community-based forms of organization, for instance, chime with anarchism. Given liberation theology's indebtedness to socialist thought, this is probably not surprising. Rarely, however, is anarchism explicitly mentioned in liberation theology, and rarely is a specific criticism of the state expressed in arguments more familiar to anarchists. Indeed, empowerment of the oppressed is often envisaged in statist terms. Yet just as anarchism is

\footnotetext{
${ }^{59}$ T. Lewis, ed., Electing Not to Vote: Christian Reflections on Reasons for not Voting (Eugene, OR: Cascade, 2008.

60 J. Ellul, Violence: Reflections from a Christian Perspective, trans. C. Gaul Kings (London: SCM, 1970).

${ }^{61}$ K. Hebden, Seeking Justice: The Radical Compassion of Jesus (Alresford, UK: Circle, 2013).

62 R.E. Osborn, Anarchy and Apocalypse: Essays on Faith, Violence, and Theodicy (Eugene, OR: Cascade, 2010).
} 
ideologically close to (indeed arguably a stream of) socialism, anarchist theology is not far removed from liberation theology. Linda Damico's The Anarchist Dimension of Liberation Theology explores precisely this ideological proximity, ${ }^{63}$ and Keith Hebden's Dalit Theology and Christian Anarchism illustrates this proximity in the particular postcolonial Indian context of Dalit theology. ${ }^{64}$

Similar arguments can be made of pacifist theology. One of the main reasons some Christian anarchists (Tolstoyans in particular) are anarchists is that they apply their pacifist rejection of violence to the state- - they see their anarchism as a consistent and essential extension of their pacifism. Conversely and as already noted in passing, some Christian anarchists have found support in arguments made by leading theologians such as Yoder or Hauerwas who, although not anarchists, have articulated powerful theological cases against violence.

A more recent school of theological thought which at times echoes anarchist themes is Radical Orthodoxy, in particular in some of the writings of William T. Cavanaugh. ${ }^{65}$ This theological current aims to return to and affirm "orthodox" interpretations of Christian faith such that, implicitly or explicitly, it is critical of contemporary ideas and institutions such as secularism but also of the modern sovereign nation-state established by the Peace of Westphalia in 1648. Even if its main concern is not necessarily with politics and even if its critical engagement with much secular thought brings it into direct philosophical conflict with much anarchist thinking, when some of its scholars engage with political questions, it can find itself

\footnotetext{
63 L.H. Damico, The Anarchist Dimension of Liberation Theology (New York: Peter Lang, 1987).

${ }^{64}$ K. Hebden, Dalit Theology and Christian Anarchism (Farnham, UK: Ashgate, 2011).

${ }^{65}$ W.T. Cavanaugh, "A Fire Strong Enough to Consume the House: The Wars of Religion and the Rise of the State," Modern Theology 11 (1995), 397-420; W.T. Cavanaugh, "The City: Beyond Secular Parodies," in Radical Orthodoxy: A New Theology, ed. J. Milbank, et al. (London: Routledge, 1999); W.T. Cavanaugh, "Killing for the Telephone Company: Why the Nation-state is not the Keeper of the Common Good," Modern Theology 20 (2004), 243-74.
} 
close to an anarchist position. Richard Davis recently completed a doctoral thesis precisely on Cavanaugh and Milbank (possibly the most notorious theologian in this school) which discusses their critique of the state on theological grounds, using the language of creation, preservation and redemption to examine the origins of the state and present the church (in the "radical orthodox" sense) as an alternative to it. ${ }^{66}$ Most secular anarchists will presumably reject the grounding in theology as well as the critique of secularism, but Radical Orthodoxy nonetheless presents an example of theology which leans towards anarchism in its critique of the state.

At the same time, even when the state or capitalism are criticized theologically, rarely do theologians openly adopt the "anarchism” label. This reluctance might be driven by a degree of caution and distrust based on the perception that anarchists inexorably dismiss all things religious, or perhaps sometimes to avoid lengthy justifications of the appropriateness of the label. But this seems to be changing. In both activist and scholarly circles, there is a palpable buzz around religious (especially Christian) anarchism, and in religious groups in particular an apparent desire to articulate and discuss it theologically. Whether in current research projects, online discussion fora, recent publications or conference papers, there is perceptible enthusiasm for more explicitly anarchist-leaning theology.

One example is the quality of theological discussions hosted on websites such as Jesus Radicals, whether in essays and podcasts, ${ }^{67}$ at conferences convened through it, or in publications emerging from these. ${ }^{68}$ Also interesting and indicative of the up-to-date appeal of anarchist theology is Kevin Snyman's Occupying Faith, which is a collection of sermons,

\footnotetext{
${ }^{66}$ R. Davis, "The Political Church and the Profane State in John Milbank and William Cavanaugh" (University of Edinburgh, 2013).

67 Jesus Radicals' "Iconocast” podcast, for example, includes interviews with a substantial list of American theologians.

${ }^{68}$ For example, Van Steenwyk's That Holy Anarchist.
} 
reflections, and other resources placing Jesus among the Occupy movement and exploring how Christians can respond "though prayer, meditation, liturgy, stories, art, reflection and theological debate" to today's "unjust economic and political systems." ${ }^{69}$ Mohamed Jean Veneuse's ambitions for "Anarca Islam" is similarly rooted in the contemporary political economy and blends exegesis with more theological considerations.

In any case, anarchist theology is not entirely new. As already noted, several established schools of theological thought have hovered close to anarchist conclusions. Hundreds of articles printed in the Catholic Worker newspaper since its launch (in 1933) have echoed central anarchist themes using theological language. Moreover, most of the books mentioned above as "exegetical" also at times engage in more "theological" reflection and arguments, as do their authors in other publications. For instance, Ellul, Boyd, Wink, Yoder and Andrews, to name but a few, have published theological works which lend themselves well to Christian anarchist arguments. As to Gary Snyder's Buddhist Anarchism, it also probably best comes under the category of "theology" rather than "exegesis" in that it articulates anarchist reflections from a Buddhist position. ${ }^{70}$ What examples such as these illustrate, therefore, is that the recent burst of scholarship on anarchist theology has older foundations to build upon.

A more controversial set of theological publications might perhaps be qualified as "polemics," "tracts,” or "pleas” (an analogous French term might be plaidoyer). For instance, Jacques de Guillebon and Falk van Gaver’s L'Anarchisme chrétien blends an avowedly selective reading of renowned French Catholic theologians with meandering discussions of anarchist themes and expected figures such as Tolstoy, Ellul and Day, thus painting a deliberately

\footnotetext{
${ }^{69}$ K. Snyman, Occupying Faith: Resources for Worship, Meditation, Reflection and Study (2013), available online at https://www.smashwords.com/books/view/290593.

70 G. Snyder, Buddhist Anarchism (1969), available online at http://www.bopsecrets.org/CF/garysnyder.htm.
} 
controversial yet rich and stimulating canvas. ${ }^{71}$ Another example might be Paul Cudenec's The Anarchist Soul, which journeys through the anarchism of Bakunin, Landauer and Read, but also through esoteric forms of religion, psychology and existential philosophy to present anarchism as a complete way of being in contrast to the alienating life of modern society. ${ }^{72}$ One could also mention Kerry Thornley’s Zenarchy: unorthodox in its structure, provocative in its arguments, typical of its author, it describes itself as "a way of Zen applied to social life," a "non-combative, non-participatory, no-politics approach to anarchy intended to get the serious student thinking.” Such publications may not follow traditional or academic lines of argument, but they do offer thought-provoking contributions to anarchist theology. ${ }^{73}$

Lastly, the recent work of Simon Critchley ought to be mentioned here because it engages with theology even though it is not "theological" in the sense of speaking from within a theological tradition. Both his "Mystical Anarchism” and his Faith of the Faithless journey through Schmitt’s political theology, Rousseau's civil religion, and medieval mysticism and millenarianism in order to reflect on the mystical, anarchist, and arguably millenarian potential for love of fellow humans to transform both the self and our understanding of the common. ${ }^{74}$ Critchley is not speaking from a Christian context, but his work is "theological" in the sense that it contributes to what Schmitt understood as "political theology" (which sees political discourses and institutions as secularized theological ones), and it discusses the theological work of medieval mystics and millenarians. Ted Troxell's "Christian Theory” arguably adds to Critchley (and to the view that all politics is in some ultimate sense "theological") by bringing into careful

\footnotetext{
71 J. de Guillebon and F. van Gaver, L’Anarchisme Chrétien ( Paris: L’Oeuvre, 2012).

72 P. Cudenec, The Anarchist Revelation: Being What We're Meant To Be (Sussex, UK: Winter Oak, 2013).

${ }^{73}$ K. Thornley, Zenarchy (1997), available online at http://www.impropaganda.net/1997/zenarchy.html.

${ }^{74}$ S. Critchley, "Mystical Anarchism," Critical Horizons: A Journal of Philosophy and Social Theory 10 (2009), 272-306; S. Critchley, The Faith of the Faithless: Experiments in Political Theology (London: Verso, 2012).
} 
dialogue a number of post-anarchist themes with theological reflections articulated by John Howard Yoder, thus presenting Yoder as a potential contributor to post-anarchist theory. ${ }^{75}$

In short, anarchist theology refers to diverse modes of analysis which are relatively distinct from anarchist exegesis, although complementary. As anarchist exegesis is gaining increasing recognition, so, too, is anarchist theology. Several schools of theological thought have come close to anarchist territory in the past, but rarely have theological discussions explicitly embraced anarchist reasoning and conclusions. More recently, however, a number of scholars and activists have been developing theological reflections that are sympathetic to and driven towards anarchist themes and arguments, so it seems likely that anarchist theology will continue to bear a variety of fruits in the coming years.

\section{Religious Anarchist History}

A third and more loosely defined type of scholarship in which anarchism and religion encounter each other presents and analyzes the thought and biography of specific thinkers and movements. This type of scholarship varies between the more biographical and the more discursive, some studies concentrating on mapping the lives and genealogies of individuals or movements and others more concerned with reflecting on or discussing their ideas and philosophies, perhaps drawing parallels and charting currents across different historical contexts. What is common to such studies despite significant variety is their concern to present (indeed often recover and affirm) the life and thought of religious anarchist figures—-who did what when, how this was religious and anarchist, and why it matters for the broader histories of those contexts.

\footnotetext{
${ }^{75}$ T. Troxell, “Christian Theory: Postanarchism, Theology, and John Howard Yoder,” Journal for the Study of Radicalism 7 (2013), 37-60.
} 
Examples of such studies abound, and include: studies of Tolstoyan colonies; ${ }^{76}$ Charlotte Alston's monograph on Tolstoyism as an international movement; ${ }^{77}$ Valerio Pignatta's (Italian) book on sixteenth-century English religious revolutionaries; ${ }^{78}$ Bojan Aleksov's history of religious dissenters in early twentieth century Hungary; ${ }^{79}$ André de Raaij’s account of Dutch Christian anarchists in the same period; ${ }^{80}$ Harold Barclay's short book describing various religious sects and his earlier article centered more narrowly on Muslim communities; ${ }^{81}$ Patricia Crone's presentation of ninth-century Muslim anarchists; ${ }^{82}$ Anthony Fiscella's panoramas of Islamic anarchist individuals and movements; ${ }^{83}$ Tripp York’s biographies of Dorothy Day, Clarence Jordan and the Berrigan brothers; ${ }^{84}$ the several studies chronicling the lives of Catholic Worker individuals and communities; ${ }^{85}$ as well as, of course, the autobiographical publications

${ }^{76}$ See, for example, W.H.G. Armytage, “J. C. Kenworthy and the Tolstoyan Communities in England,” American Journal of Economics and Sociology 16 (1957), 391-404; M.J. De K. Holman, "The Purleigh Colony: Tolstoyan Togetherness in the Late 1890s," in New Essays on Tolstoy, ed. M. Jones (Cambridge: Cambridge University Press, 1978), 194-222.

${ }^{77}$ C. Alston, Tolstoy and His Disciples: The History of a Radical International Movement (London: I. B. Tauris, 2013).

${ }^{78}$ V. Pignatta, Dio L'Anarchico: Movimenti rivoluzionari religiosi nell'Inghilterra del Seicento (Milano: Arcipelago Edizioni, 1997).

${ }^{79}$ B. Aleksov, "Religious Dissenters and Anarchists in Turn of the Century Hungary," in Christoyannopoulos, Religious Anarchism, 47-68.

${ }^{80}$ A. de Raaj, "A Dead Seed Bearing Much Fruit: The Dutch Christian Anarchist Movement of the International Fraternity,” in ibid., 69-81

${ }^{81}$ H.B. Barclay, Religious Movements: Today and Yesterday (London: Freedom Press, 2011); H.B. Barclay, "Islam, Muslim Societies and Anarchy,” Anarchist Studies 10 (2002),105-18.

82 P. Crone, “Ninth-Century Muslim Anarchists,” Past and Present 167 (2000), 3-28.

${ }^{83}$ A.T. Fiscella, "Imagining an Islamic Anarchism: A New Field of Study Is Ploughed," in Christoyannopoulos, Religious Anarchism, 280-317; A.T. Fiscella, Varieties of Islamic Anarchism: A Brief Introduction (2012), available online at http://www.ru-a.org/2012/03/varieties-of-islamic-anarchism-zine.html.

${ }^{84} \mathrm{~T}$. York, Living on Hope While Living in Babylon: The Christian Anarchists of the Twentieth Century (Cambridge: Lutterworth, 2009).

${ }^{85}$ See, for example, M.C. Segers, "Equality and Christian Anarchism: The Political and Social Ideas of the Catholic Worker Movement," Review of Politics 40 (1978), 196-230; P.G. Coy, ed., A Revolution of the Heart: Essays on the Catholic Worker (Philadelphia: Temple University Press, 1988); L. Holben, All the Way to Heaven: A Theological Reflection on Dorothy Day, Peter Maurin and the Catholic Worker (Eugene, OR: Wipf and Stock, 2010); M.H. Ellis, Peter Maurin: Prophet in the Twentieth Century (Eugene, OR: Wipf and Stock, 2003); M. and L. Zwick, The Catholic Worker Movement: Intellectual and Spiritual Origins (Mahwah, NJ: Paulist, 2005). 
of some of those individuals; ${ }^{86}$ John Clark’s overview of anarchist-leaning and "nature-affirming spiritualities” including Daoism, Buddhism, Zen and many more; ${ }^{87}$ John Rapp’s accounts of the anarchist impulse in the Dao De Jing, in Daoist philosophers and poets, and in more recent Chinese figures; ${ }^{88}$ and Michael T. Van Dyke's chapter on Kenneth Rexroth's Zen and anarchist leanings and on the post-war spiritual counter-culture in San Francisco. ${ }^{89}$

One could also mention Jesse Cohn’s presentation of Jewish anarchists; ${ }^{90}$ studies of Jewish anarchists prior to the First World War in the United States, Central Europe, and London; ${ }^{91}$ Bertolo’s edited volume bringing together the proceedings of a conference on anarchism and Jews (2001); ${ }^{92}$ research on the role of Judaism on the radicalism of anarchists such as Emma Goldman (Gornick 2013); ${ }^{93}$ as well as works by and about thinkers such as Martin Buber and Gustav Landauer, for instance. However, one difficulty here is that “Jewish” is a label that is as cultural and ethnic as it is "religious," and-apart perhaps from Buber—it is not always very clear how far Jewish anarchists are anarchists based on specifically religious arguments.

\footnotetext{
${ }^{86}$ See, for example, D. Day, The Long Loneliness: The Autobiography of the Legendary Catholic Social Activist (New York: Harper, 1952); A. Hennacy, The Book of Ammon (Baltimore: Fortkamp, 1994); C. O’Reilly, Remembering Forgetting: A Journey of Non-violent Resistance to the War in East Timor (Sydney: Otford, 2001).

87 J. Clark, “Anarchism," in Encyclopedia of Religion and Nature, ed. B. Taylor (London: Continuum, 2005), 49-56: 49.

88 J.A. Rapp, "Daoism and Anarchism Reconsidered,” Anarchist Studies 6 (1998), 123-52; J.A. Rapp, “Anarchism or Nihilism: the Buddhist-influenced Thought of Wu Nengzi," in Christoyannopoulos, Religious Anarchism: New Perspectives, 202-225; J.A. Rapp, Daoism and Anarchism: Critiques of State Autonomy in Ancient and Modern China (London: Continuum, 2012).

${ }^{89}$ M.T. Van Dyke, "Kenneth Rexroth’s Integrative Vision: Anarchism, Poetry, and the Religious Experience in Post-World War II San Francisco," in Christoyannopoulos, Religious Anarchism, 226-248.

90 J. Cohn, Messianic Troublemakers: The Past and Present of Jewish Anarchism (n.d.), available online at http://www.zeek.net/politics_0504.shtml.

${ }^{91}$ F. Biagini, Nati Altrove: Il movimento anarchico ebraico tra Mosca e New York (Pisa: Biblioteca F. Serantini, 1998); M. Löwy, Rédemption et Utopie: Le judaïsme libertaire en Europe centrale (Paris: Presses Universaires de France, 1988); W.J. Fishman, East End Jewish Radicals 1875-1914 (Nottingham: Five Leaves, 2004).

92 A. Bertolo, ed., L'anarchico e l'Ebreo: storia di un incontro (Milan: Elèuthera, 2001).

${ }^{93}$ V. Gornick, Emma Goldman: Revolution as a Way of Life (New Haven, CT: Yale University Press, 2013).
} 
There are therefore clearly many examples of publications that have narrated and reinstated the histories of religious anarchist movements and activists. These studies are rarely only descriptive and biographical, but they do perform an important role in writing or rewriting oft-neglected religious anarchists back into their historical contexts, in presenting some of their original contributions and telling the story of their political and religious impact. They paint a rich tapestry of religious anarchist practice (and thought) across time and space, thus empowering contemporary practice (and thought) with historical perspective.

In addition to those publications, Tolstoy and Ellul are two particular Christian anarchist authors who have enjoyed significant attention over the years, with many publications providing relatively integrated studies of both their thought and biography. Predictably, given his notoriety as a great writer of fiction, countless biographies and analyses of Tolstoy have been published in many languages. However, the specifically anarchist aspects of his later thought are rarely explicitly engaged with. Numerous studies discuss his unconventional religious views, but his political ones tend to be more quickly dismissed as too eccentric, or only described in passing or in rather vague terms. This applies as much to the scholarship on Tolstoy as to the many news articles, documentaries, and other publications which commemorated the centenary of his death in 2010. Still, a few studies have nonetheless directly engaged with both his religious and his anarchist thought. Alexandre Christoyannopoulos listed several of these in an Anarchist Studies article, ${ }^{94}$ and a few others have been published since. Colm McKeogh’s Tolstoy’s Pacifism, for instance, is one notable recent study which presents Tolstoy's religious and political ideas, including his anarchist thought, in significant depth. ${ }^{95}$ Rosamund Bartlett’s recent biography also

\footnotetext{
94 A. Christoyannopoulos, “Leo Tolstoy on the State: A Detailed Picture of Tolstoy's Denunciation of State Violence and Deception,” Anarchist Studies 16 (2008), 20-47.

95 C. McKeogh, Tolstoy's Pacifism (Amherst, NY: Cambria, 2009).
} 
gives some space to Tolstoy's anarchism as well as his take on religion. ${ }^{96}$ By and large, however, the vast scholarship on Tolstoy tends to focus on other aspects of his writings than his anarchist thought, or if it does touch on the latter it does so in vague and frequently dismissive terms.

Jacques Ellul is the other particularly notable Christian anarchist whose thought has been the subject of a number of scholarly publications. One recent example is an issue of the Ellul Forum, which includes four essays devoted to taking seriously the anarchist dimension of his thought. ${ }^{97}$ In general, however, as with Tolstoy, the anarchist elements of Ellul's thought are rarely engaged with in much detail. Indeed, Frédéric Rognon’s Générations Ellul, ${ }^{98}$ which lists and briefly describes the various "successors" of Ellul's thought today, only includes three “anarchists," even though his Jacques Ellul does include some discussion of Ellul's anarchist thought and its relevance for contemporary ecological and global justice movements. ${ }^{99}$ Of the biographies of Ellul, however, Andrew Goddard's is perhaps the one which analyzes Ellul's religious and anarchist thought in most detail. ${ }^{100}$ Still, most of the scholarship on Ellul's social and political work tends to engage with his analysis of the technological society more than with his (admittedly less abundant) explicitly anarchist musings.

In terms of historical figures and their thought, there are also well-known thinkers who are not usually identified as religious anarchists, but whose thought, some have argued, is closer to anarchism than typically acknowledged. For instance: Peter Marshall presents William Blake

\footnotetext{
${ }^{96}$ R. Bartlett, Tolstoy: A Russian Life (London: Profile, 2010).

97 A. Alexis-Baker, ed., Anarchism and Jacques Ellul (South Hamilton, MA: The International Jacques Ellul Society, 2011).

${ }^{98}$ F. Rognon, Générations Ellul: soixante héritiers de la pensée de Jacques Ellul (Geneva: Labor et Fides, 2012).

99 F. Rognon, Jacques Ellul: une pensée en dialogue (Geneva: Labor et Fides, 2007).

${ }^{100}$ A. Goddard, Living the Word, Resisting the World: The Life and Thought of Jacques Ellul (Milton Keynes, UK: Paternoster, 2002).
} 
as a forerunner of modern anarchism; ${ }^{101}$ Christopher Hobson examines Blake’s perception of Jesus and how it informs his anarchist-leaning politics; ${ }^{102}$ Mitchell Verter discusses Emmanuel Levinas' use of the term anarchy and the extent to which his thought resonates with that of classical anarchists; ${ }^{103}$ and Richard Davis argues that Søren Kierkegaard’s call for indifference to the state makes him a peculiarly Christian type of anarchist. ${ }^{104}$

As to histories of much more recent examples, we are not aware of any scholarship aiming to comprehensively map out today's religious anarchists. The religious anarchist community, however, still appears to be growing. Religious anarchism seems particularly vibrant in North America, but significant communities are perceptible in the British Isles, in Australia and the South Pacific, as well as in continental Europe and beyond. Websites such as Jesus Radicals provide a hub and a source of information for religious anarchist networks, as do of course social media, online fora and other online tools and campaigns such as Occupy Faith. Offline, these networks organize conferences and other gatherings, and religious anarchism is practiced daily in communal living, in providing care and support for the victims of the global political economy, and in "liturgy" and agitation against the powers and for a more just global society. For many, one important aim is to affirm, through practice, alternative traditions which are more faithful to scripture or to the origins of their particular religion, and in so doing to engage mainstream coreligionists as well as anarchist comrades and the broader citizenry. In any case and despite their similarities, today's religious anarchists are rooted in a variety of religious

\footnotetext{
${ }^{101}$ P. Marshall, William Blake: Visionary Anarchist (London: Freedom Press, 1994).

102 C.Z. Hobson, “Anarchism and William Blake’s Idea of Jesus,” The Utopian 1 (2000), 43-58.

103 M. Verter, “The Anarchism of the Other Person,” in Jun and Wahl, New Perspectives on Anarchism, 67-84.

104 R.A. Davis, "Love, Hate, and Kierkegaard's Christian Politics of Indifference," in Christoyannopoulos, Religious Anarchism, 82-105.
} 
traditions and political contexts, and it will be a task for future scholarship to tell the history of their life and thought.

\section{Conclusions}

While this survey is not comprehensive, we have attempted to show the variety of ways in which anarchism and religion engage with each other. Anarchists have articulated a number of criticisms of religion, including atheist dismissals of religion; but not all anarchism is atheist or takes a negative approach to religion. Critical anarchist questioning, including by religious anarchists, of dogmatic claims and oppressive institutions continues, but religion is not the only target, nor is "religion” necessarily the main or only problem.

Anarchist exegesis is a slightly different mode of analysis than anarchist theology. It is one thing to study and try to interpret faithfully the founding texts of a religious tradition, and another to ponder specific contemporary challenges and phenomena from within the language of a religious understanding (and without necessarily even having clear scriptural guidance to refer back to). As the more historical studies introduced in the fourth section shows, the reading of founding religious texts has encouraged anarchist tendencies across the centuries, and the scholarship covered in the second section underpins such interpretations. The more intellectually innovative and challenging scholarship, however, is probably in anarchist theology, where sincere reflections and musings about various questions confronting the world are articulated in ways that seek to resonate within the authors' religious traditions.

The impact of "anarchism" in religious studies is therefore varied: sometimes anarchism criticizes religion; sometimes parallels are noted between anarchist and religious ideas and practices; sometimes scriptural interpretations lead to anarchist conclusions; sometimes 
theologians lean towards anarchist themes in their religious debates; sometimes historical individuals and movements are studied and reinstated; and meanwhile, many religious anarchists try to live out their religious anarchism. The intersection of anarchism and religion has been a very vibrant area of study in recent years, with much interest not only from academics, but also anarchists and religious people in the wider community. Yet many avenues of research remain ripe for original explorations, not least in religions other than Christianity.

In a global arena witnessing what some scholars have described as a "resurgence" of religion, anarchist encounters with religion are not likely to become rarer. In that context, the emergence of religious anarchism radicalizes religion and thus empowers religious people to join anarchist ranks, builds bridges with fellow travelers confronting similar anarchist struggle, and with a good balance of respect and critical enquiry can enrich both anarchism and religious studies with a better understanding of anarchism, religion and religious anarchism. 